\title{
FACTORS CONTRIBUTING TO BULLYING IN THE EDUCATIONAL MILIEU
}

\section{Olena Fomichova}

PhD, Postdoctoral Student at the Department of Social Work and Rehabilitation, National University of Life and Environmental Sciences of Ukraine, Ukraine e-mail: evshulga2013@gmail.com,orcid.org/0000-0001-6567-9227

\section{Andrzej Kryński}

Professor, Ph.D., Polonia University in Czestochowa, Interdisciplinary Faculty, Poland e-mail: a.krynski@ap.edu.pl,orcid.org/0000-0001-9635-023X

\section{Summary}

This article examines the factors (causes) of bullying in secondary educational institutions as a form of abuse or bullying of some children (adolescents) over others. Statistical data on the prevalence of the studied negative phenomenon in Ukraine and in the world is given; the need for new scientific research on the factors contributing to bullying in the educational milieu is noted with the view to develop an effective strategy for the prevention and counteraction of bullying. A number of scientific points of view on the bullying determination were analyzed; the key personal attributes of the main participants in the bullying relationship were highlighted. Attention is focused on the role of victimhood in the victim's behavior as a direct cause of bullying, passive, unconscious bully provoking to commit illegal, antisocial violent actions. Other psychological factors of bullying are also being investigated. Particular attention is paid to social factors that directly or indirectly contribute to the emergence of bullying relations at the level of a social group, the issues of deformation of family relations and their cause and effect relationship with bullying at school are highlighted. Based on the study, the author's approach to the classification of the factors contributing to bullying in the school milieu, in accordance with their nature, is proposed.

Keywords: bullying, factors, reasons, determinants, school, adolescents, harassing, bullying.

DOI https://doi.org/10.23856/3905

\section{Introduction}

Bullying, or harassment at school today, is extremely common and fraught with a number of psychological, physical, and social threats. It is noted in educational circles that as a result of bullying, a number of psychological (decreased self-esteem, impaired socialization, maladjustment), medical (injuries), pedagogical (school maladjustment, academic failure), and other negative consequences are inflicted on a person (Bedukh, 2019). This phenomenon is a nationwide problem and occurs both in adult social groups, at work, or at school, and among young people. However, it should be noted that in the overwhelming majority of cases, bullying is widespread among groups of adolescents in general secondary educational institutions, whereof it originates, because it is the school that acts as the so-called "agent" of socialization (Lushpai, 2010). This is explained by the fact that adolescents and children are most vulnerable to bullying due to their psycho-emotional lack of formation and frailty. The manifestations of bullying inhibit the normal process of their development and maturation, the bullying victim can be mentally traumatized, and the offender becomes a potential law breaker in the future.

The statistics of the bullying facts in Ukraine indicates that $67 \%$ of children in Ukraine are fraught with this phenomenon (UN Children's Fund, 2019:16); this may indicate the ineffectiveness or 
low level of effectiveness of measures to prevent, identify and combat negative manifestations among schoolchildren by teachers, parents, and society. This can be explained by both the lack of interest in the manifestations of bullying from other persons, and the incompetence of authorized entities, and the like. In our opinion, the key factor may be the lack of understanding of the causes and consequences of this antisocial phenomenon. After all, it is better to prevent any problem than to deal with its consequences, which in some cases may acquire the unavoidability character (Shulga, 2017). A clear determination of the reasons for bullying will shed light on certain weak points in the educational and upbringing process, and on certain psychological problems faced by students.

Other statistics indicate the negative impact of bullying on students' academic achievement, given that the emotional, behavioral, and physiological consequences of bullying affect students' ability to focus on academic tasks. In the countries of the Organization for Economic Co-operation and Development (hereinafter OECD), the students who show poor academic achievements at school reported on being vulnerable to verbal, physical, and behavioral bullying. Among OECD countries, schools, where the presence of bullying is higher (more than $10 \%$ of students are constantly being bullied), perform on average 47 points lower in science, compared to schools where bullying is rare (less than $5 \%$ of students are constantly bullied) (Tishenko, 2015:15). Transferring specified indicators on the country scale, a threatening situation of a rapid potential drop in the level of success among schoolchildren is developing, which will certainly affect the general state of education and economy of the state in the future. Given this understanding of the causes, or factors of bullying in secondary educational institutions will allow a deeper understanding of its illegal, antisocial nature, in which conditions it originates and develops. However, the most important task of researching the causes of bullying in secondary educational institutions is the possibility of using their understanding to develop measures to counter and prevent these manifestations in the future. Understanding the reasons will allow us to find mechanisms for their prevention and establishment in society or a social group of a favorable educational environment for the development of a student/child as a person, the formation of a psychologically and physically healthy element of society.

Despite the fact that the issues of researching the causes, conditions, and factors of bullying in schools have been worrying domestic and foreign science for several years, in particular, such experts as I. Berdyshev, A. Barlit, A. Barlit, S. Burova, M. Dmiyrenko, I. Kon, A. Korol, A. Lavrynenko, Kh. Leimann, D. Lein, K. Lorenz, L. Lushpai, D. Olveus, V. Panok, V. Synov, etc. addressed the study of the harassment problems in the educational environment, the problem is not exactly settled down yet.

\section{Body text}

Bullying in general secondary educational institutions, as a form of cruel treatment or harassment of some children (adolescents) over others, is a global problem, it is common in countries such as the USA, Norway, England, Ireland, the Netherlands, Portugal, Australia, Japan, Brazil, Canada, etc. (Conn, 2004), and unfortunately, Ukraine is no exception. This, in turn, makes the problem of finding anti-bullying mechanisms to be international. It is difficult to say in which of these countries and at what time this negative phenomenon originated, but it can be said with all certainty that each of them has suffered as a result of bullying, that most often they experience shame and humiliation, and as a result, lack of self-confidence. Despite this, victims of bullying usually do not want to ask their parents or teachers for protection, or even prefer not to talk about the facts of bullying, as a result of which the manifestations of bullying become more frequent, and the victim becomes even more closed up. Bully or a group 
of bullies, in this case, remains unpunished, which, as we know, can only increase their desire to continue unlawful manifestations in the future. Impunity can increase the self-confidence of the bully, and therefore encourage repeated cases of bullying over the offended, and potentially increases the risk of becoming a person as a criminal in the future.

\section{Different approaches to defining bullying factors}

Today there are a number of approaches to understanding the causes of bullying in the scientific community. In particular, some scholars attribute a misconception about the admissibility and acceptability of aggressive behavior towards weaker members of the group; attempts to stand out and look more authoritative among age mates; the discretion in this way of attracting the attention of adults; boredom, compensation for failures in school or social life; pressure or abuse of parents, lack of due attention to the child, to the reasons of bullying (Garrett, 2003). Others associate the causes of bullying primarily with the characteristics of the victim itself, who becomes the object of bullying by other schoolchildren due to its inherent low status in the social group, the existence of problems associated with learning, and social behavior (Ariaev, 2014). In general, subscribing to the view of scientists, we note that learning challenges can occur both in the bully and in the person suffering from bullying, as well as other elements of deformation of social behavior. In our opinion, it is the low status of a person in a social group that is the determining personal factor in bullying, while the other two elements (learning and behavioral problems) are more universal, which fit both the character of a bully, and in general, in most cases, they do not just precede bullying but are its consequences. In addition, the abuser may also have the above characteristics. Traditional and imperishable in bullying is the fact that the bully, in comparison with the victim, has a higher social status in the social group, accompanied by the existing imbalance of power between him and the victim.

In general, the personal attributes of the bully and the victim is a problem widely discussed in pedagogy. So, E. Ozhyeva identifies personal factors causing a child to desire to commit bullying, to which the scientist refers a violent and impulsive character, a low level of empathy, concentration on his own needs and feelings, the predominance of the desire for control over peers before the desire to establish friendly or intimate relations (Ozhieva, 2009). Others include such factors to the reasons for bullying as a struggle for leadership; the conflict of various subcultures, values, views and the inability to tolerate them; aggressiveness and victimization; the child has mental and physical disabilities; grudging; lack of special leisure, etc. (Volynets, 2005). The position proposed by D. Olveus seems to be quite interesting, who saw the essence of bullying not in the aggression or anger of the offender itself, but in contempt, disrespect - a strong feeling of disgust for the uncomplaining one who would not deserve respect. The offender grants himself the privileges of dominance, control, the right of exclusion and isolation of victims (Olweus Dan, 1993).

Please note that the internal characteristics of the participants in a bullying structure are not in themselves, and will inevitably lead to the emergence of a bullying relationship at the level of a social group. In particular, the presence of physical disabilities in a person, although it is one of the personality factors, increases the probability of bullying, but independently, uncoupled from other personal, psychological, and social factors, does not in itself lead to bullying. Bullying is always associated with a combination of many factors and occurs when personal and psychological factors are superimposed on factors related to the external environment wherein social relationships are implemented. 


\section{Victim behavior as a special factor of bullying}

An important role in the formation of bullying in the school environment is played by victim behavior, the behavioral pattern of a person, manifests itself in the commission of certain actions or inaction and contributes to or causes other persons to use violence against them (psychological or physical). Victim behavior refers to psychological factors and is a direct cause of bullying, passive, unconscious provocation of the bully to commit illegal, antisocial actions. In the theory of criminology, the category of "victimization" is considered as a set of congenital or socially acquired biophysical, psychological or social personality traits that interact with external conditions and increase the likelihood of becoming a victim of a crime. These properties attract the attention of the criminal, form his criminal intent (Iurchenko, 2004). In this case, the cause is not one bully, that is, its psychological characteristics, but the victim, his subconscious behavior, in this case, acts as a catalyst, and causes aggressive manifestations from the milieu. A potential victim, in this case, subconsciously attracts the offender to himself, awakening in the latter a desire to harassing the victim. Moreover, the victim does this unconsciously, and therefore often cannot independently control his own behavior. That is, by demonstrating victim behavior, the person thus transfers himself into the status of a potential victim.

Some scholars believe, on the contrary, that victim behavior occurs in a person who suffers from bullying, that is, the manifestations of bullying themselves are the cause of the emergence of victim behavior in a potential victim. So, Papusha V.V. notes that the formation of victim behavior occurs under the influence of situational determinants. The presence of objective rigors of life: violence at school (bullying) and in the family, family deprivation; conflicts, and cardinal changes in significant spheres of life of a teenager incline him to the indiscretion of his actions and actually narrows the ability to foresee and avoid negative consequences (Papusha, 2018). In our opinion, this is not a mistake, however, in relation to bullying; victim behavior should be primary when the bully feels it in a potential victim of bullying. Considering the well-known fact that one person can treat another as the latter allows him to do it, we believe that the victim can thereby provoke the bully to harassment with his own insecurity and nervousness, low social status, etc. On the other hand, if a person does not have victim behavior, antisocial manifestations may not occur in the bully. Therefore, accepting the opinion of the scientist, we consider it appropriate to highlight the primary role of victim behavior in relation to bullying.

The scientific literature remarks that typical bullying victims also have their own characteristics: they are shy, vulnerable, private and shy; they are often anxious, insecure, unhappy, and have low self-esteem; they are prone to depression and more often than their peers think about suicide; if they are boys, they may be physically weaker than their peers (Pribytkova, 2017). More serious psychological disorders can also cause bullying. So, scientists attribute bipolar personality disorder to a particularly threatening factor of bullying, that is a mental illness that causes a person to have periodic depression, mania, or a symbiosis of both, leads to a decrease in the level of social functioning in an educational institution, family, with peers, etc. (Emotional and behavioural disorders of children and adolescents, 2003). These psychological factors are inherent mainly in potential victims of bullying, although they can also arise in offenders, especially when it comes to mania and mood swings. You should also pay attention to the biophysical and social traits of the victim, catalyzes the bully to commit bullying, which feels insecure with imaginary or real defects in appearance (physical disabilities, etc.), and this state is reflected in the appearance of the potential victim and his behavioral patterns, which provokes the bully to active illegal actions. Although this factor is rather conditional, it is 
directly related to psychological factors. If a person does not feel comfortable through clothing, imperfections in appearance, etc., he becomes more closed-up and insecure. This is reinforced by the biased attitude from individual representatives of a given social group and can act as a formative factor in victim behavior.

\section{Personality factors}

We also draw your attention that the very line between personal and psychological consequences is very conditional. In our opinion, personality factors are the primary level, a trigger in the formation of a bullying relationship. Without the presence of personal factors of bullying as a destructive social interaction, the latter cannot take place at all, in contrast to psychological factors, which are secondary and do not lead to bullying in themselves, but are increasing the likelihood of violence in a social group. We also consider it appropriate to note that most of the named psychological and personal factors are not universal only for bullying. They act as determinants for other variants of conflicts of social interactions, offenses, crimes, and the like. Therefore, the priority of identifying them is a highly topical task.

Not the least role among the factors of the bullying origin in the school educational environment is played by the general background, that is, the features of the environment where the relationship between students is realized. So, it is a well-known fact that many external factors influence the process of personality socialization. The inner world of a person is not a closed system that is formed in isolation from the surrounding community, on the contrary, people, and even more so children, are prone to external influences. A considerable number of studies indicate the existing negative influence of current television on children and adolescents (many adolescents, after watching stories with pictures of cruelty, aggressiveness, suicide, identify themselves with such heroes and act accordingly) (Halstead, 2006), which forms in the latter the perception of violence as a common model of relationships. Among the social factors, it is advisable to recall the general cultural and economic situation in the country, which inevitably affects the relationship of students with parents, teachers, and among themselves. In addition to the above, social determinants of bullying can also include the issues of a lack of professional skills to prevent and combat bullying of staff of secondary educational institutions and many more factors.

Separately, it should be mentioned the determinants of bullying associated with the deformation of family relationships. In the scientific literature, they usually include the absence of normal, balanced relations in the family, too weak, or hypercritical control by parents, neglect of their desires and needs, negative influence on the part of parents in terms of imposing aggressive behavior on the child (Garrett, 2003). The last thesis has found its own confirmation in the studies of foreign scientists, who have established a causal relationship between bullying and severe physical punishment by parents. Thus, foreign studies only confirm the fact that bullying occurs more often in those groups of children to whom their parents applied severe punishment at home (Poltavets, Pervii, Zhabokritskii, 1998). The problem of domestic violence is still critical, and the manifestations of bullying, unfortunately, are not the only consequences of the abuse of a child. The challenge of deformation of family relations and its impact on bullying at school, in our opinion, is too broad and cannot be fully covered at the level of this work. It is relatively independent and requires a separate study. 


\section{Conclusions}

Of course, bullying as a negative phenomenon, just like crime, cannot be eradicated at all. However, minimizing the bullying manifestation in secondary educational institutions is one of the priority tasks of the modern state and society. We are convinced that among other currently known tools for countering bullying, the broad implementation should acquire measures aimed precisely at eliminating the causes (factors) of bullying in the educational milieu. It is under the condition of creating a favorable environment in society, school, family, providing proper psychological and social assistance to children, the latter will be more motivated to study, active leisure, tolerance, respect for others, and to the development of their own talents than to bullying and harassment at school.

Based on the analysis of the existing causes (factors) of bullying in educational institutions, the latter should be classified, depending on nature, as:

- personality factors: violent and impulsive character, low level of empathy, concentration on one's own needs and feelings, thirst for control over peers, struggle for leadership, low level of tolerance, physical disabilities (imaginary or real defects in appearance (physical disabilities, unkempt appearance, etc.)), boredom, grudging, etc.;

- psychological factors: victim behavior; mental disorders and disabilities (bipolar personality disorder, etc.), misconceptions about the admissibility and acceptability of aggressive behavior towards weaker members of the group, etc.

- social factors: the clash of different subcultures, values, and views, the lack of special leisure for children, the low level of professional awareness of teachers and the administration of secondary educational institutions about bullying and measures to combat it, the economic, cultural, and educational crisis in the country, etc.

- family factors: lack of normal family relations, too weak, or hypercritical control by parents, neglect of the child's desires and needs, lack of due attention, use of aggressive parenting methods by adults, and the like.

\section{References}

Ariaev M. L. (2014) Osoblyvosti ta proiavy shkilnoho bulinhu na modeli Odeskoo rehionu [Peculiarities and manifestations of school bullying on the model of Odessa region]. Perinatolohiia i pediatriia: nauchno-prakticheskii zhurnal / Nats. akad. med. nauk Ukrainy, In-t pediatrii, akusherstva i hinekolohiii NAMN Ukrainy. Kyiv. - No 3. - P. 70-74. - The text of the article is available at: http://nbuv.gov.ua/UJRN/ perynatology_2014_3_20 [in Ukrainian] Bedukh A. A. (2019) Bulinh: prychyny ta sposoby podolanniia. Navchanniia, vykhovannia ta rozvytok u konteksti zhyttievykh perspektyv osobystosti: Zbirnyk materialiv Vseukrainskoi naukovo-praktychnoi internet-konferentsii z mizhnarodnoiu uchastiu [Bullying: causes and ways to overcome it.]. Berdiansk, Ukraine, April 25, 2019. - 355 p., p. 13-17 [in Ukrainian] Conn Kathleen. (2004) Bullying and Harassment: A Legal Guide for Educators. - Association for Supervision and Curriculum Development. - P. 218. [in English]

Emotional and behavioural disorders of children and adolescents (2003) World mental health day. A Global World Mental Health Education Program of The world Federation for Mental Health, 2003. [in English]

Garrett Anne G. (2003) Bullying in American schools: causes, preventions, interventions. McFarland. - P. 172. [in English] 
Halstead D. (2006) The bully around the corner: changing brains - changing behaviors. Brain Power Learning Group, Canada, 2006. - P. 151. [in English]

Iurchenko O.Iu. (2004) Rol viktymnoi povedinky poterpilykh pryvchynenni tiazhkykh nasylnytskykh zlochyniv proty zhyttia ta zdorovia osoby $v$ Ukraini [Role of victim behavior of victims in the commission of serious violent crimes against life and health of a person in Ukraine]: extended abstract of dissertation of the Cand. of Jur. Sciences: 12.00.08 / O.Iu. Iurchenko; National University Yaroslav Mudryi Law Academy of Ukraine. - Kh.,. -. 16 p. [in Ukrainian]

Lushpai L. (2010) Dosvid Velykoi Brytanii shchodo podolannia bullinhu u serednii shkoli. [The experience of the United Kingdom in overcoming bullying in high school.] The text of the article is available at: http://dspace.tnpu.edu.ua/bitstream/123456789/7866/1/Lushpai.pdf [in Ukrainian]

Olweus Dan. (1993) Bullying at School: What We Know and What We Can Do. - Blackwell Publishing. - P. 140 [in English]

Ozhieva E. (2009) Bulling kak raznovidnost nasiliia. Shkolnyi bulling [Bulling as a kind of violence. School bullying] / E. Ozhieva. - Kh., p. 44 [in Russian]

Papusha V.V. (2018) Psykholoho-pedohohichni chynnyky zapobihaniia viktymnii povedintsi pidlitkiv. (Psychological and pedagogical factors of prevention of victim behavior of adolescents.) Dissertation on competition of a scientific degree of the Candidate of Psychological Sciences Kyiv 270p. The text of the article is available at: http://psychology-naes-ua.institute/files/pdf/ papusha_dis_new_1518969168.pdf c. 198 [in Ukrainian]

Poltavets V. I., Pervii V. S., Zhabokritskii S. V. (1998) Agressivnoe povedenie pri rasstroistvakh lichnosti. [Aggressive behavior in personality disorders.] Monograph - Dnepropetrovsk: ArtPress, 1998 . - 80 p. [in Russian]

Pribytkova N. O. (2017) Bullinh u zakladakh osvity: ponniattia, struktura, prychyny ta shliakhypodolonnia. Suchasni problemy pravovoho, ekonomichnoho ta sotsialnoho rozvytku derzhavy. [Bullying in educational institutions: the concept, structure, causes, and ways to overcome. Modern problems of legal, economic, and social development of the state.] Kharkiv, 2017. [in Ukrainian]

Shulga Iev. (2017) Pravovi zakhody poperedzhennia administratyvnoi deliktnosti: kryterii efektyvnosti. [Legal measures to prevent administrative tort: criteria of effectiveness.] Visnyk Natsionalnoho tekhnichnoho universytetu Ukrainy "Kyivskyi politekhnichnyi instytut". Politolohiia. Sotsiolohiia. Pravo. Kyiv. No 1-2. Pp. 247-251. [in Ukrainian]

Tishenko I. (2015) Nova Ukrainska shkola. [New Ukrainian School] January 8, 2018. The text of the article is available at: https://nus.org.ua/news/yak-buling-vplyvaye-na-riven-navchannyadoslidzhennya-pisa-2015/ [in Ukrainian]

UN Children's Fund (2019), Data from the official website (UNICEF). The text of the article is available at: https://www.stopbullying.com.ua/adults/statistics [in Ukrainian]

Volynets L. (2005) Systema zakhystu ditei vid zhorstokoho povodzhennia: navchalnometodychnyi posibnyk [System of protection of children from abuse: study guide]; State soc. service for families, children and youth. International Women's Rights Center "La Strada Ukraine”. - K.: Derzhsotssluzhba. - 395 p. [in Ukrainian] 